-Short communication

\title{
ROLE OF PROBIOTICS IN AQUACULTURE : IMPORTANCE AND FUTURE GUIDELINES
}

\author{
MD. ABDULLAH AL MAMUN*2 SHAMIMA NASREN ${ }^{1}$ AND SYED MASHEQUL BARI \\ Department of Fish Health Management, Faculty of Fisheries, Sylhet Agricultural University, \\ Sylhet-3100, Bangladesh
}

An alternative approach to manage fish health that is fast gaining attention in the aquaculture industry is probiotics, a microbial intervention approach. Probiotics have shown that they can help to increase fish growth by enhancing the feed conversion efficiency, as well as confer protection against harmful bacteria by different modes of action. The present paper shows the current knowledge of the use of probiotics in aquaculture, particularly focusing on their modes of action such as spatial and nutritional emulation, inhibitory metabolites, immunomodulation and stress-alleviating mechanism.

Key words: Probiotics, Microbial intervention, Protection, Aquaculture

Aquaculture is a steadily growing industry world over. The number of species and new technologies are increasing in aquaculture industry for raising production. Intensification has come up as a boon to meet the increasing food demand. However, diseases are stumbling block, causing huge economic loss in millions each year world over (Shankar 2016). To control bacterial and parasitic diseases, antibiotics and drugs were used indiscriminately. Antibiotic has already raised lots of criticism over its negative impact on living biota which may lead to antibiotic-resistant pathogen ((Lakshmi et al. 2013). Probiotics is one of the authenticated alternatives that can be very effective to minimize the dependence of the aquaculture industry to antibiotics (Verschuere et al. 2000, Nayak 2010, Akhter et al. 2015). Overall beneficial effects of probiotics in aquaculture is shown in Fig. 1.
The word probiotic is derived from Greek words, Pro (favour) and Bios (life) meaning 'for life'. Probiotics used in aquaculture have been broadly defined as 'live or dead, or even a component of the microorganisms that act under different modes of action in conferring beneficial effects to the host or to its environment'. The selection process (Venugopal and Suresh 2016) of probiotics can be represented as follows:-

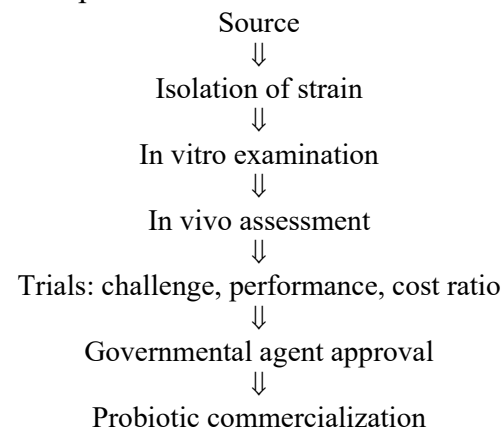

Probiotic commercialization

Probiotics are mainly of two types: (a) gut probiotics to enhance the useful microbial

* Corresponding author: <mamunff@gmail.com>.

1 Department of Fish Biology and Genetics, Faculty of Fisheries, Sylhet Agricultural University, Sylhet-3100, Bangladesh.

2 Laboratory of Aquatic Health Management, Department of Aquaculture, College of Fisheries, Karnataka Veterinary, Animal and Fisheries Sciences University, Mangalore 575002, Karnataka, India. 


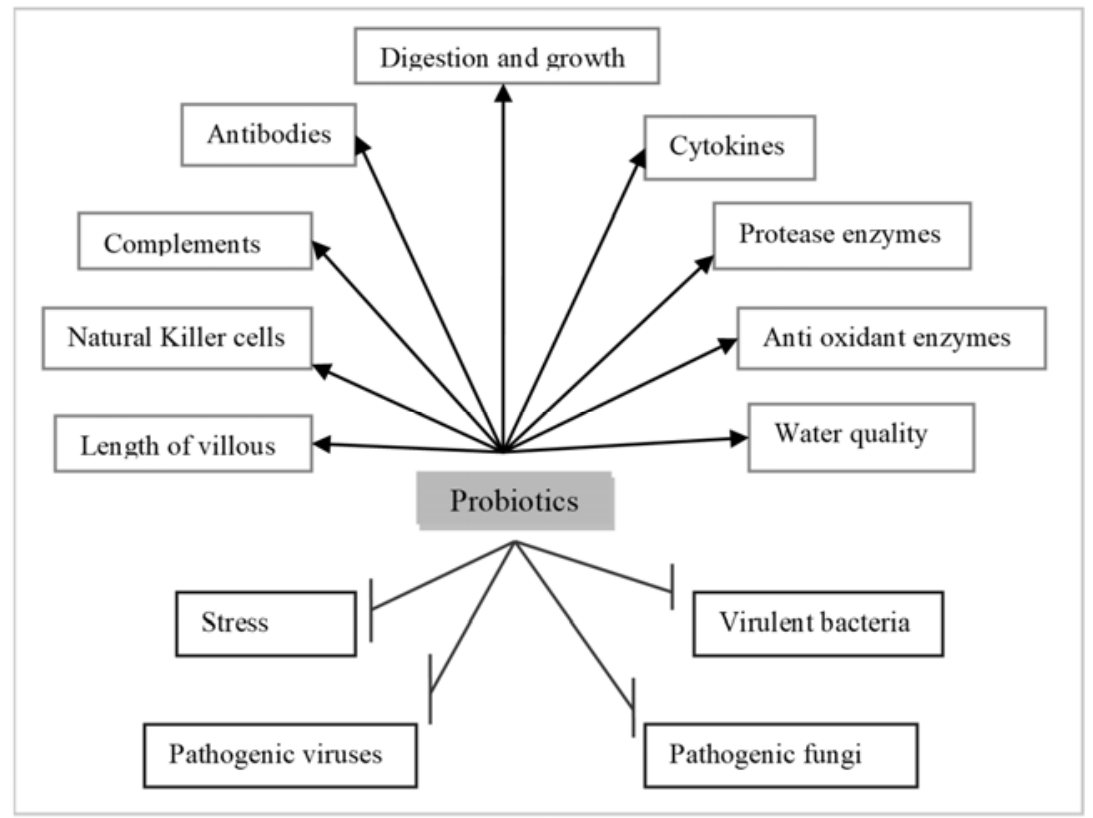

Fig. 1. Overall beneficial effects of probiotics in aquaculture, black arrow (deep black) indicates additive effects whereas light lines indicate inhibitory effects (Zorriehzahra et al. 2016).

flora of the gut and, (b) water probiotics and marketed in two forms: (i) Dry forms and (ii) Liquid forms. Liquid forms give positive results in lesser time when compared to the dry and spore form bacteria, though they are lower in density (Nageswara and Babu 2006).

Several probiotic microorganisms have been identified, attributed and applied in aquaculture. The first probiotics in aquaculture discovered long time ago was Lactobacillus sp., the lactic acid producing bacteria. Thereafter, many probiotics such as Aeromonas hydrophila, A. media, Altermonas sp, Bacillus subtilis, Carnobacterium inhibens, Debaryomyces hansenii, Enterococcus faecium, Lactobacillus helveticus, L. plantarum, L. rhamnosus, Micrococcus luteus, Pseudomonas fluorescs have been discovered.

At the beginning interest was focused on the application of probiotics as growth promoters and to improve the health of animals. Several researches have suggested that probiotic microorganisms have a beneficial effect in the digestive processes of aquatic animals. The use of probiotics as growth promoters of edible fishes, ornamental fishes and shellfishes have been tested and found promising results. 'Competitive exclusion' is an important method of probiotic bacteria where they adhere in the mucosal layer of the host and make space unavailable to the pathogenic microorganisms (Adams 2010). Production of inhibitory substances by probiotic bacteria that can prevent growth of opportunistic pathogenic microorganisms (Panigrahi and Azad 2007).

Several research publications revealed that probiotics in aquaculture have been shown antibacterial, antiviral and antifungal activity 
against known pathogens. Many microorganisms including the known probiotic group lactic acid bacteria (LAB) consume the nutrients that are essential for the growth of a number of pathogens hence make them unavailable to the pathogen (Brown 2011). Application of Gram-positive bacteria, such as Bacillus spp., is beneficial in improving the quality of the water system. Probiotic bacteria have a significant algicidal effect on many species of microalgae, particularly of red tide plankton (Fukami et al. 1997).

The disruption and destruction of quorum sensing (QS) is considered as a high potential anti-infective strategy in aquaculture (Defoirdt et al. 2004). Some probiotic bacteria such as Lactobacillus, Bifidobacterium and Bacillus cereus strains degrade the signal molecules of pathogenic bacteria by enzymatic secretion or production of auto inducer antagonists (Brown 2011).

The non-specific immune system can be stimulated by probiotics (Sakai et al., 1995). They reported that oral administration of Clostridium butyricum bacteria to rainbow trout enhanced the resistance of fish to vibriosis, by increasing the phagocytic activity of leucocytes. Bacillus sp. (strain S11) has provided disease protection by activating both cellular and humoral immune defenses in tiger shrimp (Rengpipat et al. 2000).

Stress is the primary contributing factors of fish disease and mortality in aquaculture. Using probiotic bacteria, both as a feed supplement and water can restrain stressful conditions, enhancing immune system and therefore reducing the harmful effects of various stressors (Taoka et al. 2006).
The pioneer study on the effect of probiotic supplementation on reproductive performance of fish was carried out by Ghosh et al. (2007), using a strain of B. subtilis isolated from intestine of Cirrhinus mrigala, incorporated at different concentrations to four species of ornamental fishes, in a one-year experiment. The results showed that using $B$. subtilis concentrations of $10^{6}-10^{8}$ cells $\mathrm{g}^{-1}$ of food, produced increase in the gonadosomatic index, fecundity, viability, and production of fry from the females of all four species.

A list of applications of probiotic in aquaculture is given in Table 1 .

Though several studies have shown that the probiotic concept has potential in the aquaculture sector, however, satisfactory results could not be achieved by many workers due to the sudden change of environmental factors such as temperature, poor sanitary conditions, improper management practices that lead animals into the stress. A cursory examination has shown that there is little information on the mode of action of the bacterial strain used as probiotics (Mohamed 2005). On the other hand information on the side effects of probiotics in the animal and environmental impact are scanty. Industrial companies have borrowed the probiotic preparations used in animal (veterinary) husbandry, and are directly applied into aquaculture systems without much thinking of the future consequences. Therefore, importance of probiotics in fostering sustainable approaches in aquaculture and provide avenues in furthering its research and development are essential. 
Table 1. Different applications of probiotics in aquaculture

\begin{tabular}{|c|c|c|c|}
\hline Identity of the probiotic & $\begin{array}{l}\text { Applied to aquatic } \\
\text { species }\end{array}$ & Reference & Application \\
\hline Bacillus sp. s11 & Penaeus monodon & Rengpipat et al. 1998 & \multirow[b]{2}{*}{ Growth promoter } \\
\hline $\begin{array}{l}\text { Bacillus NL 110, Vibrio } \\
\text { NE } 17\end{array}$ & $\begin{array}{l}\text { Macrobrachium } \\
\text { rosenbergii }\end{array}$ & Rahiman et al. 2010 & \\
\hline Bacillus coagulans & Cyprinus carpio koi & Lin et al. 2012 & \\
\hline L. rhamnosus & Oncorhynchus mykiss & Nikoskelainen et al. 2012 & \multirow{4}{*}{$\begin{array}{l}\text { Pathogenic } \\
\text { inhibition }\end{array}$} \\
\hline L. acidophilus & Clarias gariepinus & Abdullah et al. 2011 & \\
\hline Bacillus sp. & M. rosenbergii & Moreira et al. 2012 & \\
\hline Lactococcus lactis & Epinephelus coioides & Zhang et al. 2012 & \\
\hline Bacillus .sp, Vibrio sp. & M. rosenbergii & Rahiman et al. 2010 & \multirow{2}{*}{ Nutrient digestibility } \\
\hline L. acidophilus & C. gariepinus & Dohail et al. 2009 & \\
\hline B. coagulans & Pennaeus vannamei & Zhou et al.2009 & \multirow[t]{2}{*}{ Water quality } \\
\hline L. acidophilus & Clarias gariepinus & Dohail et al. 2009 & \\
\hline L. delbrueckii & Dicentrarchus labrax & Carnevali et al. 2006 & \multirow{2}{*}{ Stress tolerance } \\
\hline Alteromonas sp. & Sparus auratus & Varela et al. 2010 & \\
\hline Bacillus subtilis & $\begin{array}{l}\text { Poecilia reticulata, } \\
\text { Xiphophorus maculatus }\end{array}$ & Ghosh et al. 2007 & $\begin{array}{l}\text { Reproductive } \\
\text { enhancement }\end{array}$ \\
\hline
\end{tabular}

The present state of application of probiotics in aquaculture needs for intensive research and careful application.

\section{REFERENCES}

Abdullah, A. M., R. Hashim and P. M. Aliyu. Evaluating the use of Lactobacillus acidophilus as a biocontrol agent against common pathogenic bacteria and the effects on the haematology parameters and histopathology in African catfish Clarias gariepinus juveniles. Aquacult. Res. 42(2): 196-209.

Adams, C. A. 2010. The probiotic paradox: live and dead cells are biological response modifiers. Nutr Res Rev. 23: 37-46.

Akhter, N., B. Wu, A. M. Memon and M. Mohsin. 2015. Probiotics and prebiotics associated with aquaculture: a review. Fish Shellfish Immunol. 45(2): 733-741.

Brown, M. 2011. Modes of action of probiotics: Recent developments. J. Anim. Vet. Adv. 10(14): 1895-1900.

Carnevali, O., L. de Vivo, R. Sulpizio G. Gioacchini, I. Olivotto, S. Silvi and A. Cresci. 2006. Growth improvement by probiotic in European sea bass juveniles

(Dicentrarchus labrax, L.), with particular attention to IGF-1, myostatin and cortisol gene expression. Aquaculture 258: 430-438.

Defoirdt, T., N. Boon, P. Boosier and W. Verstraete. 2004. Disruption of bacterial quorum sensing: an unexplored strategy to fight infections in aquaculture. Aquaculture 240: 69-88.

Dohail, A., M. Abdullah, H. Roshada and M. Aliyu. 2009. Effects of the probiotic, Lactobacillus acidophilus, on the growth performance, haematology parameters and immunoglobulin concentration in African Catfish (Clarias gariepinus, Burchell 1822) fingerling. Aquacult. Res. 40(14):1642-1652.

Fukami, K., T. Nishijima and Y. Ishida. 1997. Stimulative and inhibitory effects of bacteria on the growth of microalgae. Hydrobiology 358: 185-191.

Ghosh, S., A. Sinha and C. Sahu. 2007. Effect of probiotic on reproductive performance in female live bearing ornamental fish. Aquacult. Res. 38 (5): 518-526.

Gioacchini, G., F. Maradonna, F. Lombardo, D. Bizzaro, I. Olivotto, and O. Carnevali. 2010. Increase of fecundity by probiotic administration in zebrafish (Danio rerio). Reproduction 140(6): 953-959. 
Lakshmi, B., B. Viswanath and D. V. R. Sai Gopal. 2013. Probiotics as antiviral agents in shrimp aquaculture. J. Pathog. Article ID 424123, p. 1-13.

Lin, S. H., Y. Guan, L. Luo, and Y. Pan. 2012. Effects of dietary chitosan oligosaccharides and Bacillus coagulans on growth, innate immunity and resistance of koi (Cyprinus carpio koi). Aquaculture, 342-343: 36-41.

Mohamed, K. S. K. 2005. Probiotics in aquaculture. In: Aquaculture Medicine and Aquatic Animal Health Management (Ed. Singh, I. S. B. and Yadava, Y. S.). Aquaculture Authority, Chennai and National Centre for Aquatic Animal Health, Kochi-684016, pp. 131-145.

Moreira, S. D., S. S. Medeiros, L. L. Pereira, L. A. Romano, W. Wasielesky and B. E. Cupertino. 2012. The use of probiotics during the nursery rearing or the pink shrimp Farfantepenaeus brasiliensis (Latreille, $1817)$ in a zero exchange system. Aquacult. Res. 43(12): 1828-1837.

Nageswara, P. V. and D. E. Babu. 2006. Probiotics as an alternative therapy to minimize or avoid antibiotics use in aquaculture. Fishing Chimes 26 (1): 112-114.

Nayak, S. K. 2010. Probiotics and immunity: a fish perspective. Fish Shellfish Immunol. 29: 2-14.

Nikoskelainen, S., A. Ouwehand, S. Salminen and G. Bylund. 2012. Protection of rainbow trout (Oncorhynchus mykiss) from furunculosis by Lactobacillus rhamnosus. Aquaculture 198: (3-4): 229-236.

Panigrahi, A. and I. S. Azad. 2007. Microbial intervention for better fish health in aquaculture: the Indian scenario. Fish Physiol. Biochem. 33: 429-440.

Rahiman, M., J. Yousuf, T. Ambat, and M. Hatha. 2010. Probiotic effect of Bacillus NL110 and Vibrio NE17 on the survival, growth performance and immune response of Macrobrachium rosenbergii (de Man). Aquacul. Res. 41(9): 120-134.

Rengpipat, S., S. Rukpratanporn, S. Piyatiratitivorakul and P. Menasaveta. 2000. Immunity enhancement in black tiger shrimp (Penaeus monodon) by a probiont bacterium (Bacillus S11). Aquaculture 191: 271-288

Rengpipat, S., W. Phianphak, S. Piyatiratitivorakul and P. Menasveta. 1998. Effects of a probiotic bacterium on black tiger shrimp Penaeus monodon survival and growth. Aquaculture 167(3-4): 301-313.

Sakai, M., T. Yoshida, S. Astuta and M. Kobayashi. 1995. Enhancement of resistance to vibriosis in rainbow trout, Oncorhynchus mykiss (Walbaum) by oral administration of Clostridium butyricum bacteria. J. Fish Dis. 18:187-190.

Shankar, K. M. 2016. Importance and scope of aquatic medicine in India. In: Training Manual on Aquatic Medicine (Ed. Patil, P.). College of Fisheries, KVAFSU, Mangalore575002, pp. 1-3.

Taoka, Y. H. Maeda and J. Y. Jo. 2006. Growth, stress tolerance and non-specific immune response of Japanese flounder Paralichthys olivaceus to probiotics in a closed recirculating system. Fish. Sci. 72(2): 310-321.

Varela, J. L., I. Ruiz, L. V. Chacoff, S. Arijo, J. M. L. Rubio, I. G Millan, M. P. M. del Rio, M. A. Morinigo and J. M. Mancera. 2010. Dietary administration of probiotic Pdp11 promotes growth and improves stress tolerance to high stocking density in gilthead seabream Sparus auratus. Aquaculture 309: 265-271.

Venugopal, M. N. and T. Suresh. 2016. Use of probiotics in Aquaculture. In: Training Manual on Aquatic Medicine (Ed. Patil, P.). College of Fisheries, KVAFSU, Mangalore575002, pp. 35-41.

Verschuere, L., G. Rombaut, P. Sorgeloos and W. Verstraete. 2000. Probiotic bacteria as biological control agents in aquaculture. Microbiol. Molecul. Biol. Rev. 64(4): 655-671.

Zhang, S., Y. Sing, M. Long and Z. Wei. 2012. Does dietary administration of Lactococcus lactis modulate the gut microbiota of grouper, Epinephelus coioides," J. World Aquacult. Soc. 43(2): 198-207.

Zhou, X. X., Y. B. Wang and W. F. Li. 2009. Effect of probiotic on larvae shrimp (Penaeus vannamei) based on water quality, survival rate and digestive enzyme activities. Aquaculture 287(3-4): 349-353.

Zorriehzahra, M. J., S. T. Delshad, M. Adel, R. Tiwari, K. Karthik, K. Dhama and C. C. Lazado. 2016. Probiotics as beneficial microbes in aquaculture: an update on their multiple modes of action: a review. Vet. $Q$ 36(4): 228-241.

(Received revised manuscript on 11 May, 2018 